\title{
Building and breaking a Large Igneous Province: An example from the High Arctic
}

\author{
Døssing Andreasen, Arne; Gaina, Carmen; Brozena, John M.
}

\section{Published in:}

Geophysical Research Letters

Link to article, DOI:

10.1002/2016GL072420

Publication date:

2017

Document Version

Publisher's PDF, also known as Version of record

Link back to DTU Orbit

\section{Citation (APA):}

Døssing Andreasen, A., Gaina, C., \& Brozena, J. M. (2017). Building and breaking a Large lgneous Province: An example from the High Arctic. Geophysical Research Letters, 44(12), 6011-6019. https://doi.org/10.1002/2016GL072420

\section{General rights}

Copyright and moral rights for the publications made accessible in the public portal are retained by the authors and/or other copyright owners and it is a condition of accessing publications that users recognise and abide by the legal requirements associated with these rights.

- Users may download and print one copy of any publication from the public portal for the purpose of private study or research.

- You may not further distribute the material or use it for any profit-making activity or commercial gain

- You may freely distribute the URL identifying the publication in the public portal 


\section{Geophysical Research Letters}

\section{RESEARCH LETTER \\ 10.1002/2016GL072420 \\ Building and breaking a large igneous province: An example from the High Arctic}

Key Points:

- An early Aptian giant High-Arctic LIP dyke swarm, $>2000 \mathrm{~km}$ long, formed as part of early rifting of the Amerasia Basin

- Middle-to-Late Cretaceous HALIP flood basalts subsequently covered the northern Amerasia Basin, centered over the proto-Alpha Ridge

- Latest Cretaceous to middle

Paleocene rifting and seafloor spreading within the Makarov Basin broke apart the proto-Alpha Ridge

Supporting Information:

- Supporting Information S1

Correspondence to:

A. Døssing,

ards@space.dtu.dk

\section{Citation:}

Døssing, A., C. Gaina, and J. M. Brozena (2017), Building and breaking a large igneous province: An example from the High Arctic, Geophys. Res. Lett., 44, 6011-6019, doi:10.1002/2016GL072420.

Received 22 DEC 2016 Accepted 6 JUN 2017 Accepted article online 7 JUN 2017 Published online 17 JUN 2017

\author{
Arne Døssing ${ }^{1}\left(D\right.$, Carmen Gaina $^{2}\left(D\right.$, and John M. Brozena ${ }^{3}$ \\ ${ }^{1}$ DTU Space, Lyngby, Denmark, ${ }^{2}$ Centre for Earth Evolution and Dynamics, University of Oslo, Oslo, Norway, ${ }^{3}$ United States \\ Naval Research Laboratory, Washington, District of Columbia, USA
}

\begin{abstract}
The genesis of the Amerasia Basin in the Arctic Ocean has been difficult to discern due to overprint of the Cretaceous High-Arctic Large Igneous Province (HALIP). Based on detailed analysis of bathymetry data, new Arctic magnetic and gravity compilations, and recently published radiometric and seismic data, we present a revised plate kinematic model of the northernmost Amerasia Basin. We show that the smaller Makarov Basin is formed by rifting and seafloor spreading during the latest Cretaceous (to middle Paleocene). The opening progressively migrated into the Alpha Ridge structure, which was the focus of Early-to-Middle Cretaceous HALIP formation, causing breakup of the proto-Alpha Ridge into the present-day Alpha Ridge and Alpha Ridge West Plateau. We propose that breakup of the Makarov Basin was triggered by extension between the North America and Eurasian plates and possibly North Pacific plate rollback.
\end{abstract}

\section{Introduction}

Despite recent years of intense geophysical data collection and interpretation, the timing of and processes responsible for forming the $2.5 \times 10 \mathrm{~km}^{2}$ Amerasia Basin (Figure 1a) remain disputed. It is generally thought that its southern part, i.e., the Canada Basin, was formed by seafloor spreading along a N-S oriented spreading segment in the Early Cretaceous [e.g., Grantz et al., 2011; Chian et al., 2016]. However, the signature of the extinct spreading segment disappears east of the Chukchi Plateau. North of here, the Amerasia Basin is dominated by flood basalts of the Cretaceous High Arctic Large Igneous Province (HALIP), which has a highamplitude, positive, and irregular magnetic signature [e.g., Gaina et al., 2011; Saltus et al., 2011]. The HALIP domain is centered over the submarine Alpha-Mendeleev Ridge complex but extends within the surrounding basins, covering a total area of $\sim 1.3 \times 10 \mathrm{~km}^{2}$ [Oakey and Saltus, 2016]. Only the northernmost Amerasia Basin, including the Makarov Basin, appears partly void of HALIP flood basalts, whereas significant volumes of HALIP rocks have also been mapped on the surrounding Arctic shelves [e.g., Dibner, 1998; Drachev et al., 2011; Evenchick et al., 2015; Estrada et al., 2016; Minakov et al., 2017].

The complex geophysical signatures and sparsity of reliable age determinations of the HALIP have facilitated radically different hypotheses to explain the origin of-and the link between-the HALIP, the AlphaMendeleev Ridge, and the Amerasia Basin [e.g., Forsyth et al., 1986; Lawver and Scotese, 1990; Lane, 1997; Cochran et al., 2006; Lebedeva-Ivanova et al., 2006; Miller et al., 2006; Dove et al., 2010; Funck et al., 2011; Grantz et al., 2011].

Here we present a new plate kinematic model for the Late Cretaceous to middle Paleocene evolution of the northernmost Amerasia Basin, focusing on the Makarov Basin and the Alpha Ridge (Figure 1a). We present a detailed analysis of bathymetry data and of new compilations of Arctic magnetic and gravity data (section S1 in the supporting information). Our model is constrained by recently published (i) U-Pb radiometric ages of HALIP intrusive rocks from Svalbard, Franz Josef Land, and Canada [Corfu et al., 2013; Evenchick et al., 2015; Estrada et al., 2016], (ii) multichannel seismic (MCS) data from the Makarov Basin [Evangelatos and Mosher, 2016] (section S2 in the supporting information), (iii) maps of HALIP intrusions in the Barents Sea [Minakov et al., 2017], and a detailed remapping of inferred Early Cretaceous HALIP dykes recently mapped in the LOMGRAV-09 aeromagnetic data between the Lomonosov Ridge and Alpha Ridge [Døssing et al., 2013a]. A more detailed discussion of the methodology can be found in the supporting information and previous published studies [Andersen et al., 2014; Blakely, 1996; Brozena et al., 2003; Døssing et al., 2013a, 2013b; Evangelatos and Mosher, 2016; Forsyth and Mair, 1984; Fullea et al., 2008; Jacobsen, 1987; Jakobsson et al., 2012; Jackson et al., 2010; Jokat et al., 2013; Lebedeva-Ivanova et al., 2011; Mosher et al., 2016; Oakey and Saltus, 2016]. 

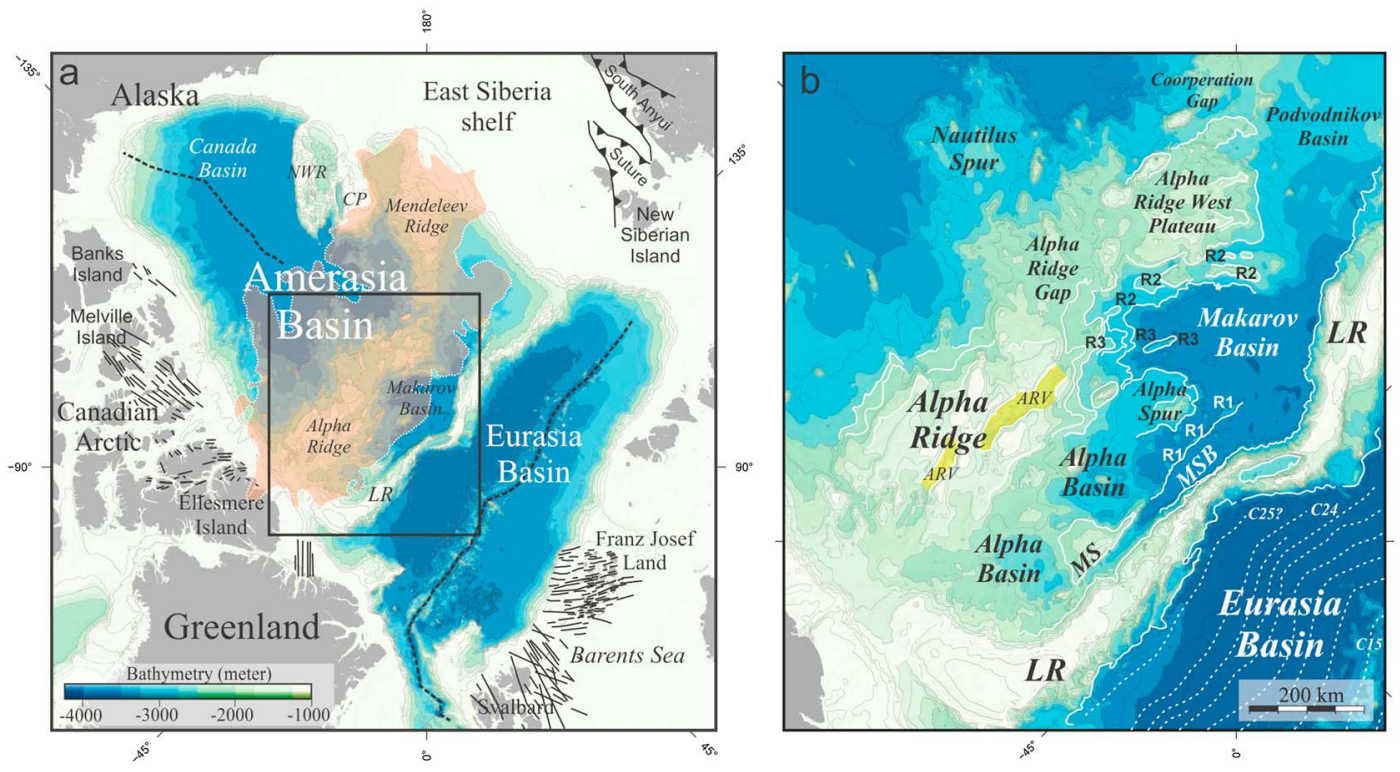

Figure 1. (a) Bathymetry [Jakobsson et al., 2012]. Orange, transparent area: HALIP flood basalts [Oakey and Saltus, 2016]. Black lines: HALIP dykes [Døssing et al., 2013a; Minakov et al., 2017]. Dotted line in Canada Basin: Extinct spreading segment. Northwind Ridge, NWR; Chukchi Plateau, CP. (b) Main study area comprising the Alpha Ridge, Lomonosov Ridge (LR), and Makarov Basin. We further distinguish between the Alpha Ridge West Plateau (ARWP), Alpha Ridge Gap (ARG), Alpha Spur, Alpha Basin, Alpha Ridge Valley (ARV), Marvin Spur (MS), and Marvin Spur Basin (MSB). The ARV is highlighted by yellow color. R1, R2, and R3 denote small bathymetric ridges discussed in text. Isochrons in Eurasia Basin: Døssing et al. [2014]. Bold white lines: Emphasized bathymetric contour lines used to highlight important tectonic features.

\section{Morphology}

The main study area (Figure 1b) comprises three main elevated features: the Alpha Ridge, the Alpha Ridge West Plateau (ARWP), and the Lomonosov Ridge (LR). Parallel to the Lomonosov Ridge, and south of its characteristic bend, runs the $200 \mathrm{~km}$ long Marvin Spur and a line of small ridges ("R1"). Together with the intervening Marvin Spur Basin (MSB), they separate the Lomonosov Ridge from the Alpha Basin and the Alpha Ridge. The R1 ridges disappear along-strike beneath the flat and deep ( $3900 \mathrm{~m}$ below sea level; $\mathrm{mbsl}$ ) seafloor of the Makarov Basin, which is demarcated by the Alpha Ridge, the ARWP, the Alpha Spur and the Lomonosov Ridge.

The Makarov Basin as a whole is c. $350 \mathrm{~km}$ long and broadens from less than $100 \mathrm{~km}$ near the Alpha Ridge to more than $200 \mathrm{~km}$ against the Lomonosov Ridge. Characteristic of the basin is a very pronounced arcuate geometry as defined by bands of parallel ridges along its margins. This is particularly evident against the ARWP where arcuate-shaped ridges ("R2") define an 70 km wide transition zone between the Makarov Basin and the elevated ARWP. On the opposite margin this arcuate geometry is outlined by the flank of the Alpha Spur against the Makarov Basin.

The seafloor of the Makarov Basin gradually shallows to less than 2500 mbsl over a distance of $150 \mathrm{~km}$ near the Alpha Ridge. Here the seafloor is interrupted in its central part by a line of small ridges ("R3") which are $10-20 \mathrm{~km}$ wide and rise up to $900 \mathrm{~m}$ from the surrounding seafloor. The R3 ridges mimic the along-axis arcuate geometry of the Makarov Basin and can be traced to the abrupt termination of the Alpha Ridge Valley (ARV): a prominent 20-40 km wide depression that intersects the central Alpha Ridge and defines a negative relief of up to $1300 \mathrm{~m}$ relative to the plateau surface of the Alpha Ridge.

\section{Gravity and Magnetic Data Analysis}

Residual magnetic data (section S3 in the supporting information) show that the Alpha Basin (and part of the Alpha Ridge) is dominated by a short wavelength, spatially coherent, sequence of linear magnetic anomalies (Figure 2a). The anomalies strike at high angle to the Lomonosov Ridge with either an NE strike (Type I) or an ENE strike (Type II) (Figure 2(d)). Most of the Type I linear anomalies were mapped by Døssing et al. [2013a], 
a

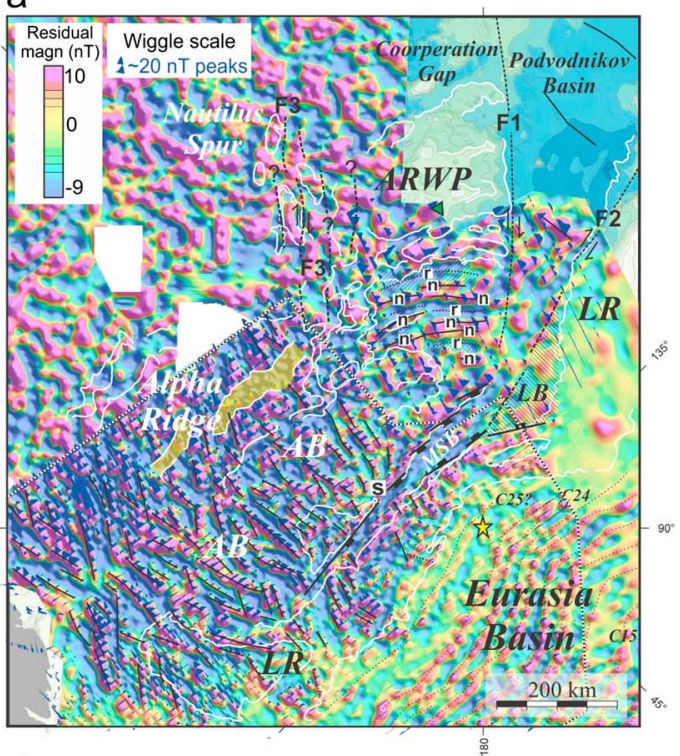

C

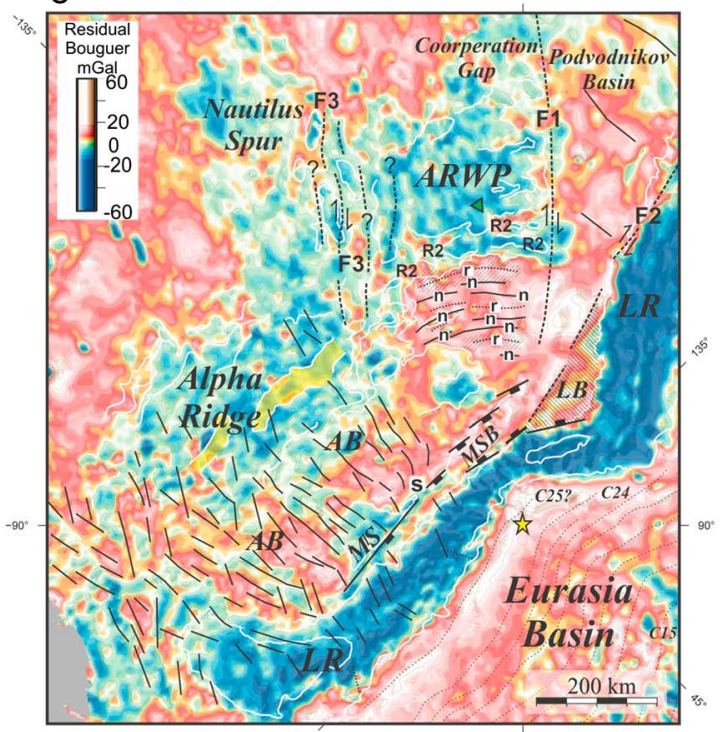

b

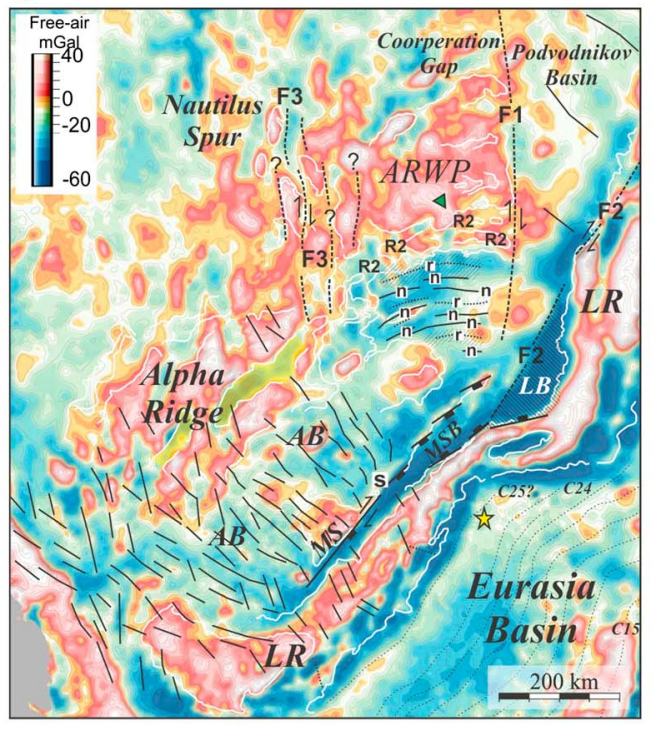

d

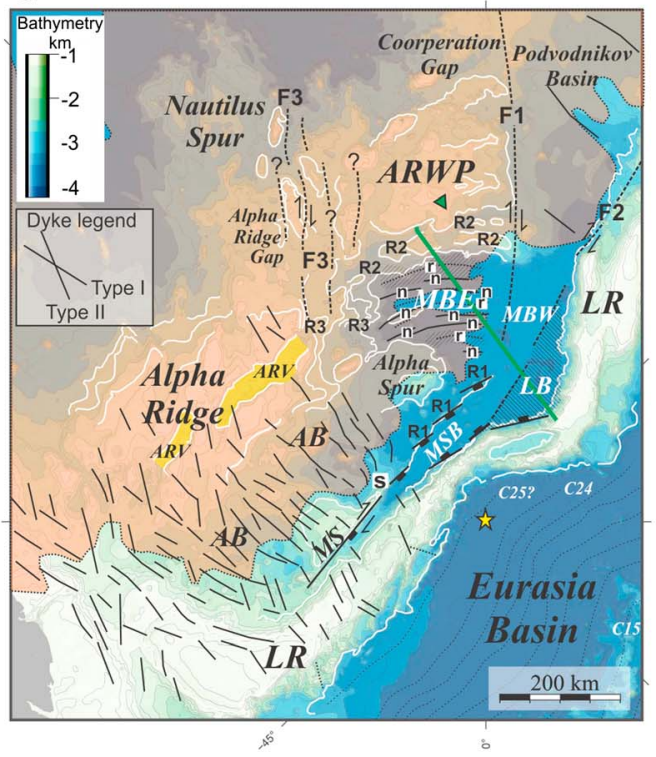

Figure 2. (a) Residual high-pass magnetic anomalies overlain by positive residual data wiggles (section $\mathrm{S} 3$ in the supporting information). Black-white dotted line: LOMGRAV-09 survey outline. (b) Free-air anomalies (section S1) (c) Residual highpass Bouguer anomalies (section S1). (d) Structural interpretation with bathymetry background. Inserted "dyke legend" shows typical orientations of the mapped Type I and II magnetic structures. "F1-F3:" Major strike-slip type fault zones (location of F3 uncertain). "R1-R3:" Small bathymetric ridges. "n-r:" Selected normal and reverse magnetic anomalies in the MBE. "s:" Eastward bends in linear magnetic anomalies in the Alpha Basin against the Marvin Spur Basin. Green filled triangle: Location of dredged basalt [Jokat et al., 2013]. Green line: MCS profile for 2-D modeling (Figure 3). Orange, transparent area: Outline of HALIP flood basalts from positive pseudogravity values (Figure S3d in the supporting information). Yellow star: North Pole. Isochrons in Eurasia Basin: Døssing et al. [2014]. Black lines in Podvodnikov Basin are broad linear magnetic highs [Kovacs et al., 1999]. Bold white lines: Emphasized bathymetric contour lines used to highlight important tectonic features (Figure 1b). Abbreviations: AB, Alpha Basin; ARWP, Alpha Ridge West Plateau; LB, Lomonosov Basin; LR, Lomonosov Ridge; MS, Marvin Spur; MSB, Marvin Spur Basin; MBE, Southern Makarov Basin; MBW, Northern Makarov Basin.

although not in the same detail as permitted here using amplitude wiggle tracks. Type II magnetic anomalies have not been mapped before. We were unable to find any consistent cross-cutting relationship between the Type I and II anomalies. Furthermore, gravity data (Figures $2 \mathrm{~b}$ and $2 \mathrm{c}$ ) indicate that some of the linear magnetic anomalies, in particular in the southern-southeastern Alpha Basin, correlate with subtle gravity anomalies, indicating that the magnetic structures are related at least partly to lithological contrasts. 
We can confidently trace the Type I and II magnetic anomalies from the Alpha Basin onto the Lomonosov Ridge (Figures 2a and 2d). This is particularly evident southeast of the Marvin Spur, where the Lomonosov Ridge lacks a prominent scarp toward the Alpha Basin. Closer to the North Pole, the Lomonosov Ridge narrows to less than $50 \mathrm{~km}$, its scarp grows, and short linear magnetic anomalies across its crest become separated from linear anomalies in the Alpha Basin by the Marvin Spur Basin, which has a nonmagnetic character. Importantly, we observe distinct eastward bends (highlighted by "s," Figure 2d) of the linear magnetic anomalies in the western Alpha Basin in the proximity of the Marvin Spur Basin.

The Makarov Basin has a very distinct bathymetric, magnetic, and gravity signature as compared to e.g., the adjacent Alpha Ridge, ARWP, Lomonosov Ridge, and Alpha Basin (Figure 2). Based on its gravity and magnetic signature, we divide the Makarov Basin into a western subbasin (MBW) and an eastern subbasin (MBE), separated by a proposed north-south oriented strike-slip fault lineament ("F1"). F1 correlates to the south with the termination of the ARWP against the Podvodnikov Basin (Figure 2d) and with the "Alpha-Mendeleev Fracture Zone" of Chernykh et al. [2016], who suggest that the structure has controlled the formation of numerous pullapart structures across the northern part of Mendeleev Ridge. We suggest that F1 correlates to the northeast with the line of R1 ridges at the boundary between the Alpha Basin and the Marvin Spur Basin. The MBW is further separated from the Lomonosov Ridge by a small basin (the Lomonosov Basin, LB), which is evident in gravity and new MCS data [Evangelatos and Mosher, 2016]. The boundary between the MBW and the Lomonosov Basin is outlined by another proposed strike-slip fault lineament ("F2"), which is defined by a steep linear gravity gradient (Figures $2 \mathrm{~b}$ and $2 \mathrm{c}$ ) that correlates toward Greenland and Eurasia, respectively, with the termination of the Lomonosov Ridge against the Marvin Spur Basin and the Podvodnikov Basin.

While the MBW has a distinct positive free-air and residual Bouguer anomaly (Figures $2 \mathrm{~b}$ and $2 \mathrm{c}$ ) and apparently isolated, spatially restricted, magnetic anomalies (Figure 2a), the MBE has an overall negative free-air anomaly signal, weakly positive residual Bouguer anomalies, and a sequence of arcuate-shaped alternating positive $(n)$ and negative $(r)$ linear magnetic anomalies. The " $n / r$ " linear magnetic anomalies parallel the arcuate-shaped R2 bathymetric ridges and morphology of the Makarov Basin as a whole (Figure 2d). The magnetic anomalies of the MBE terminate to the east-southeast near the Alpha Ridge, where they become parallel to the orientation of the Alpha Ridge Valley. Here we propose the possible location of a third strike-slip fault lineament or fault zone ("F3"), which may be subparallel to F1 and separates the MBE from the Alpha Ridge. We tentatively suggest that F3 correlates southward with small F3-parallel bathymetric and gravity structures in the depressed Alpha Ridge Gap (ARG), separating the Alpha Ridge from the ARWP.

The distinct morphology, gravity, and magnetic signatures of the MBE and MBW (Figures $1 \mathrm{~b}$ and 2) reflect an origin of the Makarov Basin that differs from the surrounding areas. A $390 \mathrm{~km}$ long MCS profile (see section S2 in the supporting information) was recently published from the Makarov Basin showing strong basement topography but otherwise flat lying, 1-2 km thick sediments [Evangelatos and Mosher, 2016]. We used the MCS profile together with the seismic line drawings of Evangelatos and Mosher [2016] as constraints in a 2-D gravity and magnetic model of the Makarov Basin and its margins in order to constrain the nature of the crust (Figure 3). The results of the modeling are described in detail in section S4 (supporting information) and discussed below.

\section{Building a LIP}

Based on a prebreakup (57 Ma) reconstruction of the Eurasia Basin (Figure 4a), the NE striking Type I magnetic anomalies and the newly mapped NNE striking Type II anomalies in the Alpha Basin (Figure 2d) are here shown to correlate, respectively, with NW striking HALIP dykes across the northern Barents Sea and with NNE striking HALIP dykes off Svalbard. The two dyke swarms in the Barents Sea converge toward the edge of the northern Barents Sea shelf. In accordance with Døssing et al. [2013a], we interpret the magnetic anomalies in the eastern Alpha Basin as dykes (or elongated sills), once part of the dyke swarms in the Barents Sea. The continuation of dykes from the eastern Alpha Basin onto the Lomonosov Ridge indicates a continental setting of this part of the Alpha Basin. We find no clear evidence that the western Alpha Basin is seated within oceanic crust. Rather, the bathymetry, magnetic, and residual gravity maps (Figure 2) indicate that the western Alpha Basin as a whole is distinct from the oceanic Makarov Basin (see below) and forms an integrated structure with the eastern Alpha Basin and possibly the Alpha Ridge which, although not fully resolved, may be continental as well [Døssing et al., 2013a, 2013b]. Some of the linear magnetic anomalies in the western 

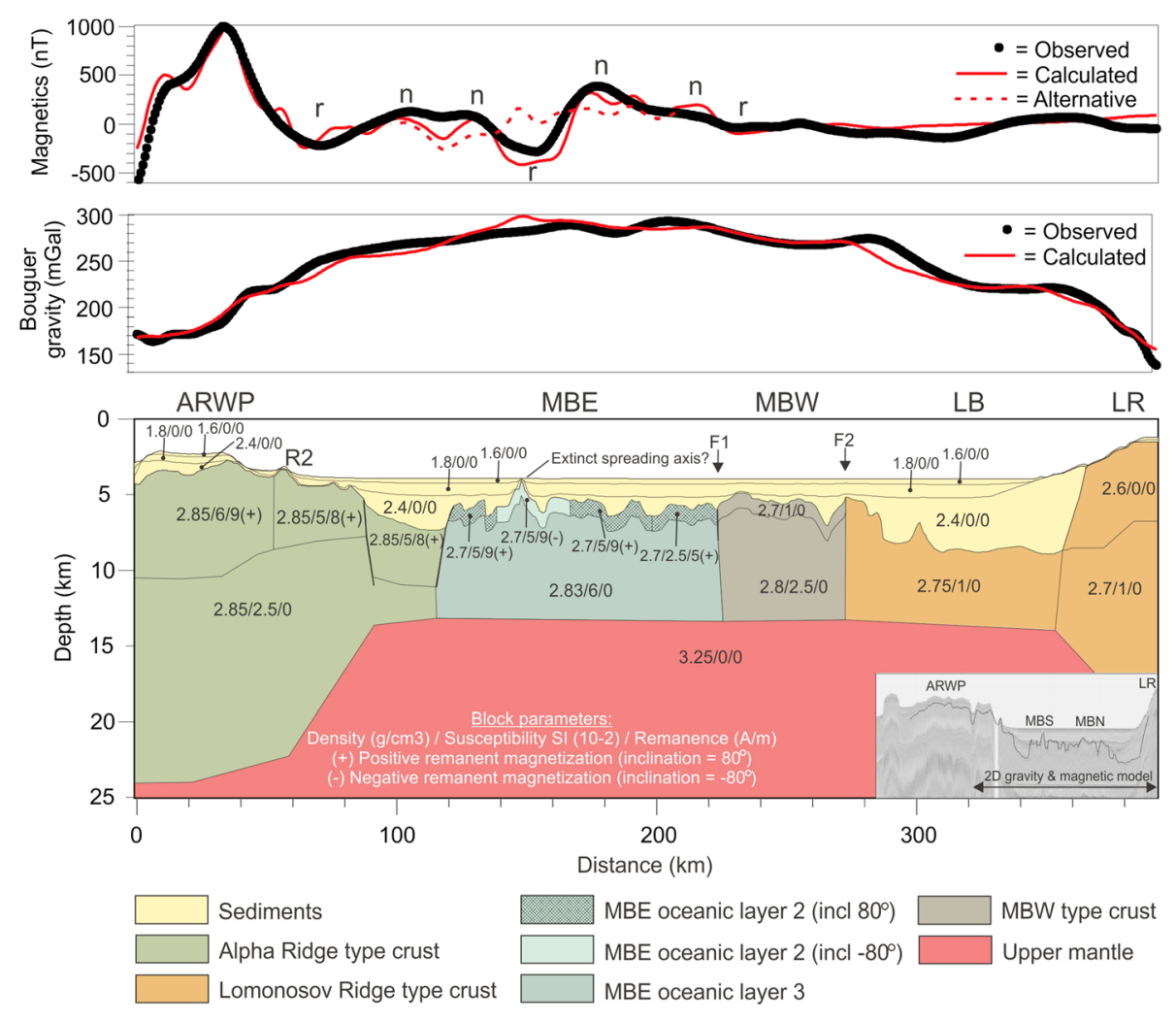

Figure 3. A 2-D magnetic and gravity model of Makarov Basin and its margins (profile location in Figure 2d). We propose that the reversed magnetized basement ridge in the central MBE (kilometer 140) represents an extinct spreading segment. Note that the alternative magnetic model using only positive remanent magnetization of all layers in the MBE results in a poor fit of the magnetic low at kilometer 140. Inset: MCS profile (section S2 in the supporting information). Abbreviations: see Figure 2. See section $\mathrm{S} 4$ in the supporting information for details on the modeling.

Alpha Basin, however, may reflect rifted basement structures, rather than dykes, which formed in relation to -or after-the mafic intrusive event of the dykes.

Recent $\mathrm{U}-\mathrm{Pb}$ radiometric results constrain the age of NW striking intrusive magmatism in Franz Josef Land to 122-123 Ma and NNE striking magnetism off Svalbard to 123-125 Ma [Corfu et al., 2013]. These results, combined with the lack of consistent cross-cutting relationships between the Type I and II inferred dykes in the Alpha Basin, indicate that the two dyke swarms may have formed as part of the same early Aptian ( 122-125 Ma) magmatic event.

The inferred HALIP dykes in the Alpha Basin and the reconstructed dykes in the Barents Sea parallel the NNE striking Queen Elisabeth Islands (QEI) dyke swarm in Arctic Canada (Figure 4a). The QEl dykes extend as far as Melville Island, and QEI-parallel dykes have recently been mapped off Banks Island [Saumur et al., 2016]. A radiometric, stratigraphic, and geophysical study [Evenchick et al., 2015] from Ellef Ringnes Island (Figure 4a) shows that the QEI dykes and associated sills correlate with elongated positive magnetic anomalies. U-Pb radiometric dating of two mafic intrusions reveals emplacement ages of $126.6 \pm 1.2 \mathrm{Ma}$ and $120.8 \pm 0.8 \mathrm{Ma}$. These ages overlap with the U-Pb ages from the Barents Sea [Corfu et al., 2013] and with other radiometric ages of HALIP magmatism in Axel Heiberg Island (126 $\pm 2 \mathrm{Ma}$ ), Ellesmere Island (122.0 $\pm 2.4 \mathrm{Ma})$, and possibly Melville Island (123 $\pm 6 \mathrm{Ma}$ ) [Evenchick et al., 2015]. Similar to Franz Josef Land [Døssing et al., 2013a], QEl intrusive activity may have started as early as $135 \mathrm{Ma}$ [Evenchick et al., 2015]. The radiometric results [Corfu et al., 2013; Evenchick et al., 2015] support the idea [Døssing et al., 2013a] of a giant early Aptian HALIP dyke swarm extending between Franz Josef Land and Melville Island. The new mapping of Type II dykes in the Alpha Basin (Figure 2d) and of early Aptian dykes off Svalbard [Minakov et al., 2017] adds an extension to the giant dyke swarm model into the northwestern Barents Sea (Figure 4a).

The Type I and II linear magnetic signature in the Alpha Basin becomes less distinct over the central Alpha Ridge, which instead is dominated by broad high-amplitude positive magnetic anomalies, typical of HALIP 
a

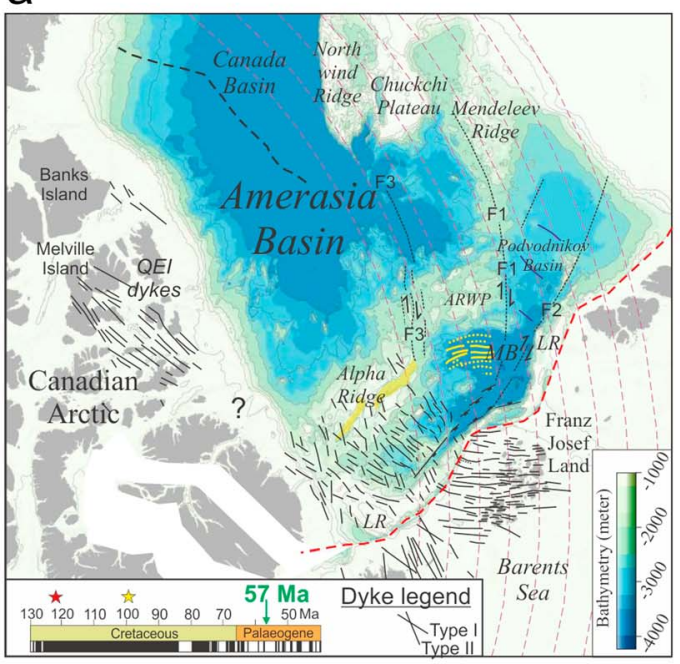

b

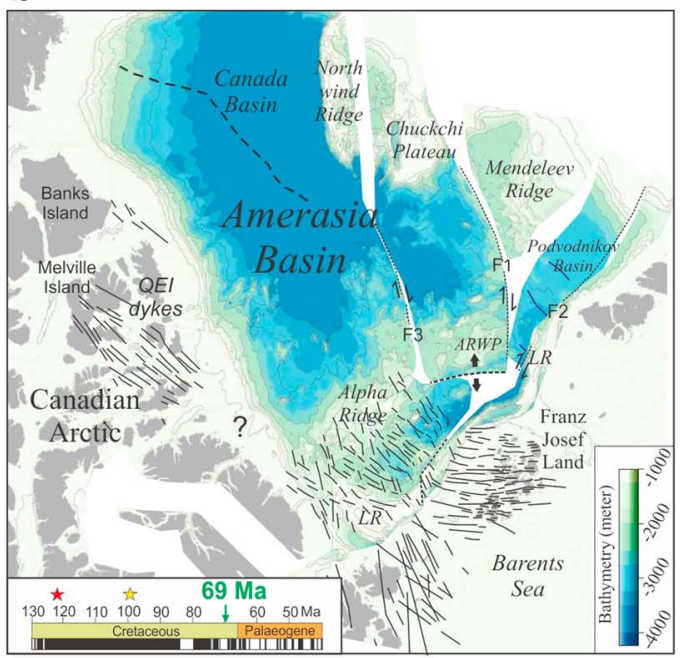

Figure 4. (a) Middle Paleocene ( $57 \mathrm{Ma}$ ) plate reconstruction showing the structure of the Amerasia Basin after the formation of Makarov Basin and before breakup of the Eurasia Basin. Solid black lines: Inferred early Aptian HALIP giant dyke swarm. Lines in Podvodnikov Basin are broad linear magnetic highs [Kovacs et al., 1999]. Red/Yellow stars in timescale inset mark ages of HALIP giant dyke swarm and main HALIP flood basalt event, respectively. Reconstructed gridded data is bathymetry. F1-F3: main transfer faults that controlled the development of the Makarov Basin. Red dashed line: Line of breakup of the Eurasia Basin. Yellow lines in Makarov Basin are magnetic anomalies interpreted as latest Cretaceous to early Paleocene rift structures (dotted) and oceanic crust (solid). Purple dashed lines: Relative motion direction between ARWP and Lomonosov Ridge as a result of the opening of Makarov Basin. (b) Late Cretaceous ( $69 \mathrm{Ma}$ ) reconstruction after initial rifting at $\sim 80 \mathrm{Ma}$ but prior to seafloor spreading in the Makarov Basin. Here we assume that the age of basement structures in the Podvodnikov Basin is older than the Makarov Basin. The ARWP is reconstructed against the Lomonosov Ridge and is flanked by the Alpha Ridge on the North American/Greenland side. Mendeleev Ridge and Chukchi Plateau and the crust between them and ARWP are moving southward during the opening of the Makarov Basin. This resulted in transtension and strike-slip motion along the transfer faults F1-F3 (see Figure 2d). The displacement between Northwind Ridge and Chukchi Plateau along F3 during the opening may have been $\sim 200 \mathrm{~km}$ in case of rigid block movement. An alternative reconstruction is shown in section S5 (supporting information) in which the Podvodnikov Basin is regarded of Late Cretaceous age. Abbreviations are: MB, Makarov Basin; QEI dykes, Queen Elisabeth Islands dyke swarm (QEI dykes). Other abbreviations: see Figure 2. See section $\mathrm{S} 6$ for rotation parameters.

flood basalts (mapped from positive pseudogravity values in Figure 2d; see also Figures S3a and S3d). The broad positive magnetic domain covers also the ARWP and has been shown [Oakey and Saltus, 2016] to extend onto the northern Ellesmere Island (Figure 1a) where it correlates with more than $800 \mathrm{~m}$ thick late Albian-Cenomanian ( 100 Ma) HALIP flood basalts of the Strand Fjord Formation [Estrada et al., 2016]. Thus, the central Alpha Ridge and the ARWP, in particular, were probably affected by extensive flood basalt volcanism and LIP buildup about $20 \mathrm{Myr}$ after the emplacement of the early Aptian HALIP dykes.

\section{Breaking a LIP}

The pseudogravity data (Figure S3d in the supporting information) indicate that thick HALIP flood basalts are missing in the central part of the MBE and MBW of the Makarov Basin (Figure 2d). The results of our 2-D gravity and magnetic modeling (Figure 3) further indicate that crust beneath the central part of the MBE has reverse magnetization and consists of typical oceanic crust that differs from thick and strongly magnetic crust of the ARWP and from overall nonmagnetic crust of the Lomonosov Ridge. Thus, the kinematic formation of the MBE (and of the Makarov Basin as a whole) may be analogous to the small Protector Basin off Antarctica [Galindo-Zaldivar et al., 2006], which has a distinct spreading ridge with morphology very similar to the reversely magnetized basement ridge in the central MBE (kilometer 140 in Figure 3). We speculate that this ridge represents the extinct spreading center of the Makarov Basin. Noteworthy, ARWP-type crust was modeled beneath the sediments along the ARWP margin of the MBE and in particular beneath the basin-parallel R2 ridges which we interpret as rift structures related to formation of the MBE. Thus, we propose that part of the ARWP was rifted and down faulted during formation of the Makarov Basin. 
The morphological and magnetic signature of the Makarov Basin, the gradual shallowing of its seafloor toward the Alpha Ridge, and the fact that we can trace the small (volcanic?) R3 ridges in the central Makarov Basin to the western termination of the Alpha Ridge Valley (Figure 2d) indicate that rifting and subsequent seafloor spreading within the Makarov Basin propagated eastward into the Alpha Ridge and may have caused the formation of the Alpha Ridge Valley. We tentatively suggest the valley may have nucleated along a preexisting weakness zone, parallel to the Lomonosov Ridge, as indicated by the single steep opposite-dipping scarps of the valley [cf. Jackson et al., 1986].

The approximate timing of seafloor spreading within the Makarov Basin can be constrained by a number of independent observations: (i) Reversely magnetized oceanic crust in the central MBE (Figure 3) implies crustal formation before or after the Cretaceous Normal Superchron ( 120-83 Ma). (ii) The consistent eastward bends of early Aptian HALIP dykes in the Alpha Basin against the Marvin Spur Basin (Figure 2d) imply postearly Aptian right-lateral deformation along the F1/F2 faults, which appear to have controlled the northern geometry of the Makarov Basin. (iii) Ar-Ar radiometric dating of a dredged basalt sample from the ARWP (position in Figure 2d) reveal an age of $89 \pm 1$ Ma [Jokat et al., 2013], that is, the presence of possible rifted ARWP-type crust along the margin of the MBE indicates spreading post $89 \mathrm{Ma}$. (iv) Interpretation of MCS data across the Makarov Basin [Evangelatos and Mosher, 2016] indicates that basement beneath the central MBE is draped by only a thin layer of inferred Late Cretaceous clastic sediments (Units 1 and 2; Figure S2 in the supporting information), thought to have been sourced from the Barents Sea margin prior to latest Paleocene breakup of the Eurasia Basin. In addition, overlying hemipelagic sediments (Unit 3) are horizontal and undisturbed, indicating that the sediments were deposited after voluminous flood basalt activity over the adjacent Alpha Ridge and ARWP.

The above constraints indicate that seafloor spreading in the Makarov Basin initiated during the latest Cretaceous, possibly imminent to breakup of the Eurasia Basin (Figure 4b). However, rifting possibly began already at $80 \mathrm{Ma}$ as supported also by 80 Myr old rift-related magmatism in North Greenland [Døssing et al., 2013b; Thórarinsson et al., 2015] and in northern Ellesmere Island at the foot of the Alpha Ridge [Estrada et al., 2016].

We suggest that the breakup of the Makarov Basin was induced by extension between the main tectonic plates-Eurasia and North America-that preceded the opening of the Eurasia Basin [Gaina et al., 2002]. In this scenario, about $200 \mathrm{~km}$ of relative motion was accommodated on the Amerasian side of the Lomonosov Ridge between $\sim 69$ to $\sim 57 \mathrm{Ma}$. We speculate that subduction of the Northern Pacific Ocean under NE Asia may have enhanced the extension in the upper plate which started by northward propagating stresses from the North Atlantic region, most probably as a diffuse plate boundary prolongation from the Baffin Bay mid-ocean ridge. The rifting and subsequent seafloor spreading in the Makarov Basin broke apart the HALIP centered over the proto-Alpha Ridge and left the ARWP isolated from the Alpha Ridge (Figure 4). Similar rifting within large igneous plateaus has been reported from the Manihiki Plateau [Nakanishi et al., 2015; Pietsch and Uenzelmann-Neben, 2016] and the Kerguelen Plateau [Rotstein et al., 1991; Whittaker et al., 2013]. We speculate that the rotational-translational movement of the ARWP block was controlled by the F1-F3 fault lineaments (Figure 2d), which probably continue toward the Chukchi Plateau, Chukchi Basin, Mendeleev Ridge, and East Siberian Shelf. Recent mapping of strike-slip faults on the East Siberian shelf supports such a Late Cretaceous to Paleocene tectonic event [Chekhovicha et al., 2015]. We propose that Late Cretaceous to middle Paleocene extension between ARWP and adjacent blocks, including the Mendeleev Ridge, lead not only to the opening of the Makarov Basin but also to the formation of the Marvin Spur Basin by transtension between the Marvin Spur and the Lomonosov Ridge (Figures 2d and 4).

Acknowledgments

Data will be available from ftp.space. dtu.dk/pub/DTU16. Thanks to Ruth H. Jackson for comments during preparation of the manuscript. A.D. was funded by the Danish Council for Independent Research. C.G. acknowledges support from the Research Council of Norway through its Centers of Excellence funding scheme, project 223272.

\section{References}

Andersen, O.B., Knudsen, P., Kenyon, S., and Holmes, S. (2014), Global and Arctic marine gravity field from recent satellite altimetry [DTU13]: Extended abstract, 76th EAGE Conf. Extended Abstracts 2014.

Blakely, R. J. (1996), Potential theory in gravity and magnetic applications, Cambridge Univ. Press.

Brozena, J. M., V. A. Childers, L. A. Lawver, L. M. Gahagan, R. Forsberg, J. I. Faleide, and O. Eldholm (2003), New aerogeophysical study of the Eurasia Basin and Lomonosov Ridge: Implications for basin development, Geology, 31(9), 825-828, doi:10.1130/G19528.1.

Chekhovicha, V. D., L. I. Lobkovskiib, M. V. Kononovb, and O. G. Sheremeta (2015), Late Cretaceous-Paleogene transform zone between the Eurasian and North American lithospheric plates, Geotectonics, 49(5), 361-378.

Chernykh, A. A., E. G. Astafurova, V. Y. Glebovsky, M. S. Korneva, A. V. Egorova, and A. G. Red'ko (2016), New data on tectonics of Mendeleev ridge and adjacent geological structures, in Doklady Earth Sciences, vol. 470, pp. 900-904, Pleiades, Moscow. 
Chian, D., H. R. Jackson, D. R. Hutchinson, J. W. Shimeld, G. N. Oakey, N. Lebedeva-Ivanova, Q. Li, R. W. Saltus, and D. C. Mosher (2016), Distribution of crustal types in Canada Basin, Arctic Ocean, Tectonophysics, 691, 8-30, doi:10.1016/j.tecto.2016.01.038.

Cochran, J., M. Edwards, and B. Coakley (2006), Morphology and structure of the Lomonosov Ridge, Arctic Ocean, Geochem. Geophys. Geosyst., 7, Q05019, doi:10.1029/2005GC001114.

Corfu, F., S. Polteau, S. Planke, J. I. Faleide, H. Svensen, A. Zayoncheck, and N. Stolbov (2013), U-Pb geochronology of Cretaceous magmatism on Svalbard and Franz Josef Land, Barents Sea Large Igneous Province, Geol. Mag., 150(06), 1127-1135.

Dibner, V. D. (1998), Geology of Franz Josef Land. No. 146. Norsk polarinstitutt.

Dove, D., B. Coakley, J. Hopper, and Y. Kristoffersen (2010), Bathymetry, controlled source seismic and gravity observations of the Mendeleev Ridge; implications for ridge structure, origin, and regional tectonics, Geophys. J. Int., 183(2), 481-502.

Drachev, S., N. Malyshev, and A. Nikishin (2011), Tectonic history and petroleum geology of the Russian Arctic Shelves: An overview, in Geological Society, London, Petroleum Geology Conference Series, vol. 7, edited by B. Vining and S. Pickering, pp. 591-619, Geological Society, London.

Døssing, A., H. R. Jackson, J. Matzka, I. Einarsson, T. M. Rasmussen, A. V. Olesen, and J. M. Brozena (2013a), On the origin of the Amerasia Basin and the High Arctic Large Igneous Province-Results of new aeromagnetic data, Earth Planet. Sci. Lett., 363, 219-230.

Døssing, A., J. R. Hopper, A. V. Olesen, T. M. Rasmussen, and J. Halpenny (2013b), New aero-gravity results from the Arctic: Linking the latest Cretaceous-early Cenozoic plate kinematics of the North Atlantic and Arctic Ocean, Geochem. Geophys. Geosyst., 14, 4044-4065, doi:10.1002/ggge.20253.

Døssing, A., T. M. Hansen, A. V. Olesen, J. R. Hopper, and T. Funck (2014), Gravity inversion predicts the nature of the Amundsen Basin and its continental borderlands near Greenland, Earth Planet. Sci. Lett., 408, 132-145.

Estrada, S., D. Damaske, F. Henjes-Kunst, B. Schreckenberger, G. N. Oakey, K. Piepjohn, K. Eckelmann, and U. Linnemannn (2016), Multistage Cretaceous magmatism in the northern coastal region of Ellesmere Island and its relation to the formation of Alpha Ridge-Evidence from aeromagnetic, geochemical and geochronological data, Nor. J. Geol., 96, 1-31, doi:10.17850/njg96-2-03.

Evangelatos, J., and D. C. Mosher (2016), Seismic stratigraphy, structure and morphology of Makarov Basin and surrounding regions: Tectonic implications, Mar. Geol., 374, 1-13.

Evenchick, C. A., W. J. Davis, J. H. Bédard, N. Hayward, and R. M. Friedman (2015), Evidence for protracted High Arctic large igneous province magmatism in the central Sverdrup Basin from stratigraphy, geochronology, and paleodepths of saucer-shaped sills, Geol. Soc. Am. Bull., doi:10.1130/B31190.1.

Forsyth, D., and J. Mair (1984), Crustal structure of the Lomonosov Ridge and the Fram and Makarov basins near the North Pole, J. Geophys. Res., 89, 473-481, doi:10.1029/JB089iB01 p00473.

Forsyth, D., I. Asudeh, A. Green, and H. Jackson (1986), Crustal structure of the northern Alpha Ridge beneath the Arctic Ocean, Nature, 322, 349-352.

Fullea, J., M. Fernández, and H. Zeyen (2008), FA2BOUG-A FORTRAN 90 code to compute Bouguer gravity anomalies from gridded free-air anomalies: Application to the Atlantic-Mediterranean transition zone, Comput. Geosci., 34(12), 1665-1681.

Funck, T., H. Jackson, and J. Shimeld (2011), The crustal structure of the Alpha ridge at the transition to the Canadian Polar Margin: Results from a seismic refraction experiment, J. Geophys. Res., 116, B12101, doi:10.1029/2011JB008411.

Gaina, C., W. Roest, and R. D. Müller (2002), Late Cretaceous-Cenozoic deformation of northeast Asia, Earth Planet. Sci. Lett., 197, $273-286$.

Gaina, C., S. Werner, R. Saltus, and S. Maus (2011), Circum-Arctic mapping project: New magnetic and gravity anomaly maps of the Arctic, Geol. Soc. London Mem., 35(1), 39-48.

Galindo-Zaldívar, J., F. Bohoyo, A. Maldonado, A. Schreider, E. Surinach, and J. T. Vázquez (2006), Propagating rift during the opening of a small oceanic basin: The Protector Basin (Scotia Arc, Antarctica), Earth Planet. Sci. Lett., 241(3), 398-412.

Grantz, A., P. Hart, and V. Childers (2011), Geology and tectonic development of the Amerasia and Canada Basins, Arctic Ocean, Geol. Soc. London Mem., 35(1), 771-799.

Jackson, H. R., T. Dahl-Jensen, and the LORITA working group (2010), Sedimentary and crustal structure from the Ellesmere Island and Greenland continental shelves onto the Lomonosov Ridge, Arctic Ocean, Geophys. J. Int., 182, 11-35, doi:10.1111/j.1365-246X.2010.04604.x.

Jackson, H., D. Forsyth, and G. Johnson (1986), Oceanic affinities of the Alpha Ridge, Arctic Ocean, Mar. Geol., 73(3-4), $237-261$.

Jacobsen, B. H. (1987), A case for upward continuation as a standard separation filter for potential-field maps, Geophysics, 52(8), 1138-1148.

Jakobsson, M., et al. (2012), The international bathymetric chart of the Arctic Ocean (IBCAO) version 3.0, Geophys. Res. Lett., 39, L12609, doi:10.1029/2012GL052219.

Jokat, W., M. Ickrath, and J. O'Connor (2013), Seismic transect across the Lomonosov and Mendeleev Ridges: Constraints on the geological evolution of the Amerasia Basin, Arctic Ocean, Geophys. Res. Lett., 40, 5047-5051, doi:10.1002/grl.50975.

Kovacs, L., V. Glebovsky, M. Sorokin, S. Mashenkov, J. Brozena (1999), New evidence for seafloor spreading in the Makarov Basin Eos Trans. AGU.

Lane, L. S. (1997), Canada Basin, Arctic Ocean: Evidence against a rotational origin, Tectonics, 16(3), 363-387, doi:10.1029/97TC00432.

Lawver, L., and C. Scotese (1990), A review of tectonic models for the evolution of the Canada Basin, in The Arctic Ocean Region, Geology of North America, edited by A. Grantz, L. Johnson, and J. Sweeney, pp. 593-618, Geol. Soc. Am., Boulder, Colo.

Lebedeva-Ivanova, N., D. Gee, and M. Sergeyev (2011), Crustal structure of the East Siberian continental margin, Podvodnikov and Makarov basins, based on refraction seismic data (TransArctic 1989-1991), Geol. Soc. London Mem., 35(1), 395-411.

Lebedeva-Ivanova, N., Y. Zamansky, A. Langinen, and M. Sorokin (2006), Seismic profiling across the Mendeleev Ridge at $82^{\circ} \mathrm{N}$ : Evidence of continental crust, Geophys. J. Int., 165(2), 527-544.

Miller, E., J. Toro, G. Gehrels, J. Amato, A. Prokopiev, M. Tuchkova, V. Akinin, T. Dumitru, T. Moore, and M. Cecile (2006), New insights into arctic paleogeography and tectonics from U-Pb detrital zircon geochronology, Tectonics, 25, TC3013, doi:10.1029/2005TC001830.

Minakov, A., V. Yarushina, J. I. Faleide, N. Krupnova, T. Sakoulina, N. Dergunov, and V. Glebovsky (2017), Dyke emplacement and crustal structure within a continental large igneous province, northern Barents Sea, Geol. Soc. London Spec. Publ., 460, SP460-4, doi:10.1144/ SP460.4.

Mosher, D. C., J. W. Shimeld, D. R. Hutchinson, and H. R. Jackson (2016), Canadian UNCLOS extended continental shelf program seismic data holdings (2006-2011), Geol. Surv. Open File Rep., 7938, 8 pp., doi:10.4095/297590.

Nakanishi, M., N. Yasuyuki, F. C. Millard, H. Kaj and W. Reinhard (2015), Topographic expression of the Danger Islands Troughs and implications for the tectonic evolution of the Manihiki Plateau, western equatorial Pacific Ocean, Geol. Soc. of Am. Spec. Pap., 511, SPE511-11.

Oakey, G. N., and R. W. Saltus (2016), Geophysical analysis of the Alpha-Mendeleev ridge complex: Characterization of the High Arctic Large Igneous Province, Tectonophysics, doi:10.1016/j.tecto.2016.08.005.

Pietsch, R., and G. Uenzelmann-Neben (2016), Paleocene Pacific Plate reorganization mirrored in formation of the Suvarov Trough, Manihiki Plateau, J. Geophys. Res. Solid Earth, 121, 7013-7023, doi:10.1002/2016JB013355. 
Rotstein, Y., M. Munschy, R. Schlich, and P. J. Hill (1991), Structure and early history of the Labuan Basin, South Indian Ocean, J. Geophys. Res., 96, 3887-3904, doi:10.1029/90JB01872.

Saltus, R. W., E. L. Miller, C. Gaina, and P. J. Brown (2011), Regional magnetic domains of the Circum-Arctic: A framework for geodynamic interpretation, Geol. Soc. London Mem., 35(1), 49-60.

Saumur, B. M., K. Dewing, and M. C. Williamson (2016), Architecture of the Canadian portion of the High Arctic Large Igneous Province and implications for magmatic Ni-Cu potential 1, Can. J. Earth Sci., 53(5), 528-542.

Thórarinsson, S. B., U. Söderlund, A. Døssing, P. M. Holm, R. E. Ernst, and C. Tegner (2015), Rift magmatism on the Eurasia basin margin: U-Pb baddeleyite ages of alkaline dyke swarms in North Greenland, J. Geol. Soc., 172(6), 721-726.

Whittaker, J. M., S. E. Williams, and R. D. Müller (2013), Revised tectonic evolution of the Eastern Indian Ocean, Geochem. Geophys. Geosyst., 14, 1891-1909, doi:10.1002/ggge.20120. 